\title{
Tabish Khair, The New Xenophobia (paperback), Oxford University Press, Oxford 2016, pp. 220
}

In Bram Stoker's Dracula, Jonathan Harker notices that he can see only his face, not Dracula's, in the shaving mirror. According to the tale, vampires are not reflected in mirrors. "Neither, one can argue, are strangers as others central to the self's identity, in the mirror of xenophobia," as Tabish Khair claims in his account about the effects of high Capitalism on xenophobia (2016: 20). Khair has also investigated the "ghosting" of the colonial/racial Other in colonial and postcolonial writers' work, thoroughly discussed in his book entitled The Gothic, Postcolonialism and Otherness, Ghosts from Elsewhere (2009). The menacing vampire is a compelling metaphor for the generic stranger in late Capitalism too. Besides, Karl Marx repeatedly described capital itself as "a vampire, an invisible, fluid, dead power that lives off the blood of the living, coming alive to the extent that it renders the living dead" (p. 13).

The author delves into xenophobia, as a fear of the stranger occasionally pushed to a paranoic state in these times of endemic uncertainty that Zygmunt Bauman called "liquid modernity" (2000: 12). This very timely book, written during the current economic and migrant crisis in Europe, examines strangers' construction in recent centuries and the different ways we respond to xenophobia. Xenophobia has been frequently considered to be a matter of prejudice, information, reason, emotion, etc., missing out that it is essentially a matter of power. This essay is navigating with grace through history, philosophy, literature and popular culture to trace xenophobia as an issue of power - it is used by "in-groups" to exert their hegemonic power over "out-groups". As Khair persuasively argues, "Xenophobia is not primarily about people. It is about power" (Khair 2016: 187).

The book's interest lies in capturing how the transformation of classical Capitalism from early money and trade-production system of power into high Capitalism has resulted in new forms of violence towards the difference, embodied by the stranger. Financial Capitalism is 
a relevant case study. It has spread across the world and serves as the dominant power structure in rich western welfare states and small, elite circuits in countries like India. Khair asserts that since global financial flows have overridden global merchandise trade, xenophobia's and stranger's forms will change in societies where power has grown more numerical and more abstract than ever before. He subsequently distinguishes the "monstrous, spectacular, and quickly identifiable" old xenophobia from the less visible, contemporary xenophobia, the "new" xenophobia, as he calls it, that operates according to him in neo-liberal high Capitalism (Khair 2016: 22, 42, 58).

Khair's book is divided into six chapters, in addition to the introduction and conclusion. The first three chapters entitled The Making of a Stranger, The Changing Face of Xenophobia and Racism, Nationalism, and Nazism, trace the theoretical contours of xenophobia as well as the historiography of "strangeness". In the fourth chapter, Capital and New Xenophobia, the conundrums of "new" xenophobia are emphasized, bred by free movement of capital and labour. The mobility of non-European labour in Europe is perceived as an "invasion", a massive threat towards the European welfare states. While welcoming the benefits of Capitalism, the latter are not ready to bear the burdens of migration. Subsequently, phenomena such as multiculturalism, Islamist terrorism, religious intolerance and class conflicts result in new xenophobia.

In one of the most analytical parts of the book, the penultimate chapter entitled Deceptive Violence, Khair scrutinizes Steven Pinker's thesis about the present decline of violence. He convincingly argues that the mode of social organization affects the kinds of violence, which is one of the core assertions of his treatise. Colonial and classical Capitalism often led to national, ethnic, or racist forms of visible xenophobic "push-out" violence. In contrast, through its changing structures of power, high Capitalism has permitted different kinds of "push-in" violence to strangers, practiced mainly at the socio-political level. Although he rightly acknowledges that physical and material violence tied to old xenophobia still exists, new xenophobia adds other, more abstracts ways of violence that "often do not even come across to us as violence per se" (Khair 2016: 6).

In the last chapter entitled New Xenophobia and Old Xenophobia, Khair's most convincing arguments involve the power of abstraction of high Capitalism, which affects the conception of the human body and the discrimination based on the legislation. As for the latter, old xenophobia "framed laws that discriminated on the basis of visible differences" (Khair 2016: 156), segregating and tagging strangers. The "new" legislation of First World countries is worded in a more abstract or "universal" manner. Still, its implementation has particular aspects inflicting those who do not belong or contribute to the high Capitalism's realms, not only outsiders, as people from the Third World but also insiders. These people share the same race or nationality with the legislator but do not have access to capital. Furthermore, Khair shapes the discord between Islam and high Capitalism in terms of embodied structures of power. Late Capitalism champions a body that simulates the abstract power of capital, circulating free from culture/religion's tyranny, quasi invisible in its normalization. In contrast, Islam, endorsing a pre-capitalist culture of physicality and material signs (i.e. dress constraints such as the burqa), claims to provide resistance to the abstract structures of identity imposed by the modern capitalist world. In other words, "new" xenophobia turns its gaze on bodies that, due to their physicality, are not fully enabled by high capital. It focuses on not all immigrants, but "illegal immigrants; not all Muslims, but religious Muslims, etc." (p. 108). This 
new kind of violence requires a constant erasure of difference, the need to swallow foreign and domestic labour into a structure of assimilation.

The book could be subject to criticism due to the binarism in its overall structure (new/ old xenophobia, Self/Other etc.). However, the author wittingly avoids a polarizing argument about Capitalism's power and Islam, as a religion uniquely resistant to it. For instance, while Khair treats Islamophobia, he criticizes, as well, Islamic states' impasses to responding to modernity's abstract logic. In order to achieve a broader understanding of the "new" xenophobia, it might be interesting to trace its appearance in the contexts of non-capitalist totalitarian societies such as China, Korea, or the former Soviet Union. One could also notice that whereas the argument about the prevalence of "new" xenophobia in western societies is quite valid, many forms of "old" xenophobic violence (e.g., concerning colour, race, ethnicity, sexuality, etc.) seem to abound in the digital space. Their strong presence there is eventually marking -quite ironically- a return to the material and the physical othering through abstract pathways (i.e. immaterial or fake identities, distance, etc.).

We could also expect a more in-depth dialogue between Michel Foucault's work and T. Khair's treatise about power and violence after the $18^{\text {th }}$ century. Several fruitful correlations with Foucault's work on normalization processes of the deviant could be considered along with Khair's arguments. For instance, Foucault's concept of "biopower" is also linked with the body and Capitalism (cf. Hardt \& Negri 2000: 23-24). According to Foucault's statement in The Will to Knowledge, "[t] his bio-power was without question an indispensable element in the development of capitalism" which made possible "the controlled insertion of bodies into the machinery of production and the adjustment of the phenomena of population to economic processes" (Foucault 1998: 140-141). It seems that Foucault's conception of power can also frame Khair's crucial distinction between the "old" and the "new" xenophobia. The Foucauldian concept of "sovereign power" with its physicality bonds with the "old" xenophobia's violence. Accordingly, the "new" xenophobia seems to correlate to the "disciplinary power" or, even better, to the "biopower" in welfare states. Finally, the Foucauldian notion of "governmentality" that has come to be widely used in investigations of how administrative organizations are able to control and regulate populations could also contribute to the discussion. This concept strongly supports Khair's reasoning that what appears today to be a progressive move away from barbarism turns out on closer inspection to involve the application of power in sustained and more subtle ways.

Khair's book, written in a captivating and highly introspective tone - even sometimes a bit repetitive of the main ideas about "old" and "new" xenophobia — contributes to a better understanding of the "civil" forms of new xenophobia, coming up in many developed countries today. We are in concordance with the author's opinion that somebody cannot combat xenophobia through preaches about love or the espousal of multiculturalism but only by insisting on human equality in terms of power, mainly based on legislation. By adopting a Foucauldian perspective, one can argue that our possibilities for action and resistance against xenophobia - considering them both on the global and individual scale — are related to our capacities to recognize and question the power structures, socialized norms, and constraints.

In this sense, it is reasonable that western societies need a non-Eurocentric, more comprehensive conception of the human self and its relationship with the world. This stance starts by welcoming difference as the source of knowledge of the self. Emmanuel Levinas's "irreducible" Other - which the author firmly takes into account in his consideration about the ethics of 
identity (Levinas 1969: 47; Khair 2016: 170-171) — certainly needs to be preserved. Nevertheless, this radical alterity does not have to lead to xenophobia or the "unconditional" hospitality of deconstruction. The latter must be unconditionally open to the absolute Other who can be neither anticipated nor understood (Caputo 1997; Derrida 2000). Richard Kearney's work on "diacritical hermeneutics" advocates the "intercommunion between distinct but not incomparable selves” (Kearney 2003: 15-18). Kearney seems to offer a pragmatic symbiotic position that stresses our need and our responsibility to differentiate others both in legal and ethical terms. Even if we adopt Khair's assumption that xenophobia is not primarily about people but about power, we still need to be able to "critically discriminate between different kinds of otherness while remaining alert to the deconstructive resistance to black and white judgements of Us versus Them" (Kearney 2003: 210).

The current rise of cybernetics and biotechnologies might bring new forms of (post) human subjectivities, new power structures, and different citizenship kinds sooner or later (cf. Nayar 2014: 100-106; Ferrando 2019: 171-182). Hence, we might encounter new Others and hardly conceivable yet forms of xenophobia. Tabish Khair's The New Xenophobia provides a well-argued and illuminating account about the stranger's fear at the present moment and strengthens our conceptual tools to deal with the challenging realities and possibilities.

\section{Peggy Karpouzou}

National and Kapodistrian University of Athens, Greece

\section{Bibliography}

Bauman Zygmunt (1997), Liquid Times: Living in an Age of Uncertainty, Polity, Cambridge. Bauman Zygmunt (2000), Liquid Modernity, Polity, Cambridge.

Caputo John D. (1997), The Prayers and Tears of Jacques Derrida: Religion without Religion, Indiana UP, Bloomington-Indianapolis.

Derrida Jacques (2000), Of Hospitality. Anne Dufourmantelle invites Jacques Derrida to respond, transl. R. Bowlby, Stanford UP, Stanford.

Ferrando Francesca (2019), Philosophical Posthumanism, Bloomsbury, London.

Foucault Michel (1998), The Will to Knowledge: The History of Sexuality, v. 1 [1976], transl. R. Hurley, Penguin Books, London.

Foucault Michel (2003), Society Must be Defended. Lectures at the College de France 1975-76, transl. D. Macey, Allen Lane The Penguin Press, London.

Hardt Michael, Negri Antonio (2000), Empire, Harvard UP, Cambridge.

Kearney Richard (2003), Strangers, Gods and Monsters: Interpreting Otherness, Routledge, London.

Khair Tabish (2009), The Gothic, Postcolonialism and Otherness, Ghosts from Elsewhere, Palgrave Macmillan, London-New York.

Levinas Emmanuel (1969), Totality and Infinity. An Essay on Exteriority [1961], transl. A. Lingis, Duquesne UP, Pittsburgh.

Nayar Pramod K. (2014), Posthumanism, Polity Press, Cambridge. 